\title{
A Comparative-Case Study of Junior High School English Curriculum between Indonesia and the Philippines
}

\author{
Rahmawati $^{1}$, Ridwan ${ }^{2}$, Jonna Mae B Calambro ${ }^{3}$ \\ \{rahmawati2497@gmail.com ${ }^{1}$, ridwan.fkipubt@gmail.com ${ }^{2}$, jonnamaebelando@gmail.com ${ }^{3}$ \} \\ English Education Department of Borneo Tarakan University, Kalimantan Utara, Indonesia ${ }^{1,2}$ \\ Jonna Mae B. Calambro, PSU Integrated School-High School, Pangasinan, the Philippines ${ }^{3}$
}

\begin{abstract}
This study aims to describe the similarities and differences between Indonesian and Filipino English curricula and other special characteristics of the two countries in the ninth grade of junior high school. The comparative case research was conducted in two schools, namely SMP Frater Don Bosco Tarakan and SMA Terpadu PSU which were selected purposively as samples. The data obtained from classroom observations, interviews, and related documents were analyzed qualitatively using concurrent analysis (data sorting, presentation, and conclusion drawing). The Indonesian and Philippine curricula have similarities in terms of aims, objectives, pedagogical standards, and evaluation standards, but differ in learning objects. Some of the specific characteristics of both curriculum practices are taking advantage of today's advanced technology, building responsibility among students, evaluating student attitudes authentically, and moving away from judging academic achievement based on exaggerated grades.
\end{abstract}

Keywords: Curriculum, English as a Second Language (ESL), English as a Foreign Language (EFL)

\section{Introduction}

It is recognized thoroughly that English is everywhere and taught for different aims. English is used all over the world, within and between communities, it is important for English to be taught in every place [1]. It hardly cannot be denied that English is used universally and thus, English is taught in many countries.

Although every country teaches English, it can be taught differently. There are a few countries that teach English as a Foreign Language (EFL) and some also teach English as a Second Language (ESL). EFL denotes to those who learn English in non-English speaking peoples and ESL refers to those who learn English where it is used as a tool for communication and is officially spoken. [2]. It implies students learn EFL in nations where English is not used as a communication apparatus, for example, Indonesia, whereas in countries where English is formally spoken like in the Republic of the Philippines, students learn ESL.

There are two sides that argue about the EFL-ESL distinction. The first side believes that the EFL-ESL difference no longer serves a useful purpose while the other side believes that the distinction is a useful one [3]. The preliminary research shows that in the Philippines where English 
is communicated as a second language, the teacher speaks bilingually in the English teaching process which is same like in Indonesia where English is learnt as a foreign language. Yet, it is found that their learning objects are enormously different. These findings then are interesting to be more investigated especially for the curriculum of the English teaching in EFL and ESL countries.

Curricculum as all the planned practice or the setting which is used to lead the students in achieving the learning goals [4]. It denotes that curriculum contains a set of plan to be applied in the learning process and it organizes how the goal of the learning itself to be achieved. Therefore, this research intended to investigate the similarities and differences of English curriculum between Indonesia and the Philippines for grade 9 of junior high school. Later, the researchers also meant to discover special characteristics of curriculum practices that might be learnt and indirectly adopted by each country.

\section{Literature Review}

\subsection{Curriculum}

Basically, the curriculum is outlined in its widest sense, and it concerns on a series of teaching and learning which is conducted in formal places [5], and as what is to be learned [6]. In a specific meaning, curriculum is defined as "the overall plan or design for a course and how the content for a course is transformed into a blueprint for teaching and learning which enables the desired learning outcomes to be achieved" [7]. In the other words, curriculum provides all aspects to help the learning process operates. It covers the whole learning practice to be implemented in a class. The syllabus, the competency, the strategies and the other aspects are organized in the curriculum. More important, it also helps to keep in track while the process of education is operating. Briefly, curriculum is a regulation to run a learning process in a country and has a fundamental function to achieve the expected goal.

A curriculum is not developed without any particular guidance. It is designed based on certain principles. a curriculum must be formulated following these four principles: (1) philosophical principles, (2) psychological principles, (3) sociological principles, and (4) miscellaneous principles [8].

Philosophical principle means developing curriculum based on ideological values that apply in society. Meanwhile, Psychological principles represent basic human values and Sociological represents social values prevailing in society. Those denote the purpose, content, and process of education must be adjusted to the conditions, characteristics and development of the community. The last is a miscellaneous principle means the curriculum should change keeping pace with the changing needs and demands of the society. This principle expects a curriculum should be flexible enough to meet the individual differences. This indicates that the principle of flexibility should be supported in developing the curriculum.

The improvement of an educational program consequently requires various successive stages [9] and they are described as follow: 
Aims and objectives. Planning the aims and objectives of the learning program becomes the first step in developing a curriculum. Aims (the most generally stated purposes) are too often sacrificed for specific learning objectives [10]. It means that aims are the general purpose that can determine what objectives will be achieved. Objectives are typically expressed in terms of expected outcomes [11]. In the other words, objectives reflect the most specific purpose.

Curriculum standard/learning objects. After determining the aims and objectives, subject areas that have been established, for example, English language needs curriculum standards, in this case the learning objects. This refers to discipline-specific and written so as to demonstrate to the students and the teacher what the students are needed to know or have the option to do toward the finish of the program of learning [9].

Pedagogic standard. The next stage in developing a curriculum is to distinguish the most applicable sequences for the transmission of educational program. This is the identification of the standard, and it comprises selecting appropriate teaching and learning methodologies. The fields of pedagogic standard are the pedagogical mode, type of learning approach, resources and technologies, formative feedback mechanisms, how students are arranged in the classroom, timings, assignments, learning assessments or formative learning models, and how the learning can be delivered to other situations [9].

Evaluation Standard. The final stage to set a complete curriculum is to develop an evaluation standard, in this case, a summative assessment. Summative assessment is an enactment evaluation which is planned to set up a documented final decision about the student's capability and it usually is taken at the end of unit classroom test, the periodical standard test, or the end-of-the-year state tests [12].

The components of curriculum, from developing the aim until the evaluation standard, should be clear and are arranged in appropriate stages. Determining the aims will derive the objectives. Having aims and objectives will draw learning objects. Then, pedagogic standard will be set up after completing the learning objects. The last, evaluation standard will evaluate whether the process on the right track or not. However, the components can be used to achieve the goal of education.

Indonesia has revised or renewed its curriculum ten times. The 1947, 1952, 1964, 1968, 1975, 1984, 1994, 2004 (Competency-based curriculum), 2006 (School-based Curriculum), and currently the 2013 curriculum are applied in stages [13]. This recent curriculum is oriented for the improvement and also the balance of knowledge, skill and behavior. It intends to encourage the better quality of gaining competencies in human resources. As time always changes, the curriculum is possible to be revised again and again. These changes are a logical consequence of changes in the political, socio-cultural, economic, and science and technology systems in the nation and state society. This is because the curriculum as a set of educational plans requires to be dynamically modernized in agreement with the demands and changes occurred in society. All Indonesian curricula were considered based on the same philoshopical foundation, namely Pancasila and 1945 Constitution, the difference is emphasized on educational goals and approaches [14].

The Republic of the Philippines has many reforms of its education system. It started from colonial to global influence. Precisely, it was began since the Spanish occupancy period in 15211898, then the United States of America period in 1900-1942, continued by the Japanese devised 
curriculum in 1942-1944 and the new one is in 2016, the Philippines autonomously applies a new curriculum namely $\mathrm{K}$ (Kindergarten) to 12 Curriculum [15].

Some curricula have also been applied in the Philippines. It is a logical consequence of the change of time. A curriculum certainly can be revised due to the needs of a country. Considering all needs, the Philippines has revised its curriculum many times to try enhancing its country.

\subsection{English as Foreign Language (EFL)}

EFL is learnt by people who live in a non-English speaking country. The need for English as a language of international communication cannot be denied by Indonesia. The development of EFL in Indonesia started before the independence phase: before 1945, then in the independence and postindependence phase: 1945-1966, the new order regime phase: 1966-1998, and last the reformation phase: 1998-present [16].

The present position of English language in Indonesia is as compulsory in high schools. Because English is a worldwide language and as the most spoken one by the worldwide citizens for many purposes, the (Indonesian) government later obliges individuals to learn it in all levels of formal education and even some private schools have introduced English from primary school to higher degree [17]. But, the 2013 Curriculum only obligates English to be taught in junior and senior high school. Otherwise, English in private schools is learnt from elementary to higher degree. In spite of this, English is not taught throughout in all levels, especially for public schools.

Experiencing occupancy from a non-native English speaker has made Indonesia instill English as a foreign language. It also needs a long journey to develop and make the position of English is legal and clear.

\subsection{English as Second Language (ESL)}

ESL is taught in an English speaking country or leant by students who live in the culture of the target language. The English language had been adopted as a medium of instruction in the Philippines since the United States of America occupancy period. In 1900, the American colonial government apparently comprised an English as the only policy to be taught in order to bond the Filipinos who had many distinctive linguistic foundations, and to provide them entrance to modernization [18].

English plays an important role as the administrative and business language in the Philippines. It is claimed that English is a formal language and treated as a medium in teaching and learning process. However, the Philippines' students study English as a supplementary language because they have different mother tongue languages [19].

\section{Empirical Investigation}

\subsection{Research Design}

The employed design in this study was a comparative case research using qualitative approach. A comparative case studies [20], also called multicase or multisite case studies, involve collecting and analyzing data from several cases and can be differentiated from the single case 
research that may have subunits or subcases embedded within. Here, the researchers gained insight into the component of English curriculum case. It was not only one case because the component of English curriculum studied was from two countries, Indonesia and the Philippines.

\subsection{Research Subjects}

The subjects were taken purposively in which [21] particular subjects were important to the research as 'typical' examples of the issue. The selected school from the Philippines was PSU Integrated School-High School because the school is a laboratory school that is known having high quality administrators. The compared school was SMP Frater Don Bosco Tarakan in Indonesia because this school was considered to have the same level and characteristics with PSU Integrated School-High School. The first location was conducted in PSU Integrated School-High school, Bayambang city, Pangasinan province, the Philippines on September 2019 and the second location was taken in SMP Frater Don Bosco, Tarakan city, Kalimantan Utara province, Indonesia on November 2019.

\subsection{Data Gathering Procedure}

Observation, interview, and documentation were used in collecting data. The observations were conducted to see the classroom activities and surrounded areas. Any activities were jotted down into a field note following Hays and Singh's format [22]. Data saturation was reached after eight observations and there was no need to observe more teaching processes.

Semi-structured interviews were then carried out using a prepared interview guide followed up with open-ended questions to seek further details and description [23], [24], and [25], and were recorded and transcribed for analysis [26].

Documents are also the sources of data [27] in this study, specifically: curriculum guide, lesson plan, textbooks, students' assignments, photos, calendar of academic, and course schedule. These documents were interpreted to articulate meaning around the topic discussed [28].

\subsection{Data Analysis}

Transcibed data were analyzed by following "three concurrent flows of activity, namely data reduction, data display, and conclusion drawing or verification" [29]. This procedure was supposed to be able to present the data in the understandable way.

\subsection{Trustworthiness}

Validity is an important key to effective research [30] because it increases the trustworthiness of the data. The trustworthiness of the data in this study was recognized by means of triangulation [31]. In this study, triangulation of sources [32] was chosen to verify the data from different types of data collection. This technique was for checking out the consistency of different data sources within the same method. It means comparing the results of observation with interview until checking interview against documents and other written evidence that can corroborate what interview respondents report. 


\section{Findings and Discussion}

\subsection{Findings}

This study was completed on January 24, 2019 after conducting research in PSU Integrated School-High School, Bayambang, the Philippines and SMP Frater Don Bosco Tarakan, Indonesia, especially for grade 9 of junior high school.

The consistency of the data had conjointly been clarified using triangulation approach based on what were found on the related documents, field note, and interview transcript. The data were assembled following the components of curriculum based on Scott's curriculum components [9], specifically: aims and objectives, curriculum standard (learning objects), pedagogic standard, and evaluation standard (summative assessment).

\subsection{Curriculum Component of Indonesia's EFL Curriculum}

Aim and Objectives. The English teaching aimed at improving students' communicative competence and literacy skills. The objective was to produce graduates who were able to communicate in three discourses: interpersonal, transactional, and functional language in written and spoken at the informational literacy level, for doing the social function, in personal, social culture, academic, and profession context [33].

Curriculum Standard/Learning Object. Learning objects for grade 9 were the interpersonal and transactional communication text, and the functional texts (for example: expression of congratulation, agreement, giving opinon and suggestion, asking for and giving clarification, narrative text, procedure text, report text, advertisement, etc.) [34].

Pedagogic Standard. The English curriculum applied a student-centered approach. The learning approach was scientific and supported by the other teaching methods such as a discovery learning. Utilized resources and technologies were book, video, audio, picture, internet, teacher's voice, natural environment, hand phone, PPt, LCD projector, and speaker. The feedback mechanism happened from the opening until the closing of teaching process. The used seating arrangement was a letter $\mathrm{U}$ or others, and it depended on the appropriate setting. The English subject took 80 minutes per meeting and there were two meetings. The tasks were written, performance, and project tasks. The types of tasks showed that the formative learning approach was authentic and followed the Anderson et al.'s cognitive process [35]. The last, the students learned outside the class.

Evaluation Standard/Summative Assessment. There were six assessments in grade 9 in which they were employed to assess knowledge and skill. They compromised written tests, oral tests, projects or presentation tasks. The attitude was assessed through observation, anecdote journal, peerassessment, and self-assessment. The result of knowledge and skill were marked with score and predicate. While the result of attitude was marked with a predicate. The follow-up of students' achievement was remediation for whom were not passed the mastery-learning target. 


\subsection{Curriculum Component of the Philippines' ESL Curriculum}

Aim and Objectives. The aim of the English curriculum was to help students acquire highly developed literacy skills. The objective of the curriculum was then to produce the graduates who apply language conventions, principles, strategies, and skills through the literature of the globe in (1) interacting with others, (2) understanding and learning other content areas, and (3) sustaining for themselves in any endeavors they may involve [36].

Curriculum Standard/Learning Object. The learning object of grade 9 itself was about the AngloAmerican literature (for example: the Epic of Beowulf, the Pardoner's Tale, and Romeo and Juliet).

Pedagogic Standard. Student-centeredness was the applied pedagogic mode. The types of learning approach were constructivist, inquiry based, collaborative, integrative, and reflective learning approach. The learning sources and technologies were book, video, picture, internet, PPt, LCD TV and projector, speaker, Manila paper, envelope, and carton. The feedback mechanism happened from the opening until the closing of teaching process. The seating arrangement was Letter $\mathrm{U}$ or orderly in-rows, but it depended on the appropriate setting. The English subject took 60 minutes for each 4 meeting. The tasks were written tests, performance/project tasks using Anderson et al.'s cognitive process. The students might learn outside.

Evaluation Standard/Summative Assessment. There were three assessments in grade 9 in which they were used to assess knowledge and skill. They were written work, performance work, and a quarterly exam. The behavior was assessed through observation using an index card. The results of the three learning domains were marked with predicate. The follow-up of students' achievement was remediation for whom were not passed the mastery-learning target.

\subsection{Discussion}

The Similarities and Differences. In view of the findings, there were similarities and differences between Indonesia's EFL and the Philippines' ESL curriculum for grade 9 of junior high school. They were analyzed through the components of the curriculum as depicted below.

Aims and Objectives. Generally, the aims and objectives of Indonesia and the Philippines' English curriculum were similar. Both curricula particularly intended to achieve communicative and literacy competencies.

Since the term 'communicative competence' refers to students' ability to use the language appropriately in different linguistic, sociolinguistic, and contextual settings, the Indonesian and Philippine curriculum similarly desire to produce the students who are able to use the English language in personal and social life. It shows that the background of English learning cannot be separated from human life. Moreover, a curriculum should also be formulated following psychological and sociological principles. The psychological principle represents basic human values and the sociological principle signifies the social value prevailing in society. The notion of literacy means the competence of comprehending and connecting the obtained knowledge for real life. 
Indonesia's EFL curriculum wants to produce graduates who are able to communicate in three discourses: interpersonal, transactional, and functional language in written and spoken at informational literacy level. In the American Library Association, it is stated that "information literacy is a set of competencies expecting students to recognize when they need the information and are aware to effectively locate, evaluate, and use it" [37]. In line with this notion, the Philippines' ESL curriculum expects the graduates to apply rule, principle, strategy, and ability in interacting with the others. In addition, they also should understand and study other fields and bring ability for themselves which can be used for encountering many things in the future. Briefly said, the aims and objectives of Indonesia's EFL curriculum and the Philippines' ESL curriculum are similar, because they commonly expect for mastering communicative and literacy skill.

Curriculum Standard/Learning Object. The curriculum standards (learning objects) of the Indonesia and Philippines' English curriculum have huge differences. In Indonesia, the content is more focused on the text based which reflects on factual, conceptual, and procedural knowledge through speaking, listening, reading and writing practices [38]. Specifically, interpersonal and transactional texts, functional texts, and monolog texts are taught as the main materials. For instance, the learning objects of grade 9 are expression of congratulation, passive voice, advertising, fairy tales or narrative, procedure texts, and report texts [33] and [34].

In the Philippines, the students learn based on literary works. Their English curriculum named Language Arts and Multiliteracies Curriculum (LAMC) in which it does not mean art course is incorporated in an English subject. The language art is defined as the study of the six modes of language, namely: listening, reading, speaking, writing, viewing, and visually representing. In the other words, it is the art of using language proficiently to communicate an idea through English skills. Therefore, in the English Curriculum Guide, it is stated that LAMC is attached in certain language acquisition, learning, teaching, and assessing principles. Multi-literacies recognize the students that there are various kinds of literacy at work in the society, so the content is types of globe literature from the Philippines and the other countries [36]. The learning object of grade 9 is the Anglo-American literature and the selections for instance, are the Epic of Beowulf, the Pardoner's Tale, and Romeo and Juliet.

Literature offers a few prominences for learning English. Literature provides ample illustrations of real-life usage of language in different circumstances and is beneficial authentic materials [39]. It also offers plenty of prospects for learners to enhance their lexical, grammatical, pragmatic, cultural, and discoursed views. Hence, Indonesia also learn English through literature, but the selection is different. The successful utilization of literature relies upon the suitable choice of literary versions. The following considerations are used to determine the selection: (1) the student's cultural background, (2) the student's linguistic proficiency, (3) the student's literacy background, (4) the student's age and level of understanding, (5) interesting texts, and (6) availability and suitability of the text [40].

Ultimately, the curriculum standard (learning object) of the Indonesia and Philippines' English curriculum for grade 9 of junior high school is not similar. Text of interpersonal and transactional conversation, and functional and monolog texts are the learning objects of Indonesia's EFL curriculum. While the learning objects of the Philippines' ESL curriculum are some selections of Anglo-American Literature. 
Pedagogic Standard. The similar pedagogic standard between Indonesia and the Philippines' English curriculum is seen from the pedagogic mode, types of learning approach, formative learning approach (including formative assessment), feedback mechanisms, tasks, sources and technologies, and the seating arrangement. Conversely, they are different on time allocation and their environment.

The first similarity is the pedagogic mode or the way the teacher interacts with the learners. The pedagogic standard represents an appropriate way to deliver the English curriculum standard (learning objects) [9]. To do so, both Indonesia and the Philippines similarly focus on student centeredness in the process of teaching and learning. The Indonesian curriculum is intended to focus on encouraging students to be effective communicators [33] and the Philippines curriculum is focused on fostering students who are communicatively competent and multi-literates [36]. These results are in line with Richards who presents that a more student-focused approach affects the quality of students' participation and interaction, and the learning outcomes [7] Utilizing this kind of interaction between the teacher and the learners as the pedagogic mode gives big chance to achieve the expected outcomes of both countries.

Indonesia requires scientific approach, while the Philippine curriculum obligates constructivist approach which is supported by integrative teaching, reflective, collaborative, and inquiry-based approach. However, they are considered as the similarity because the scientific approach in the 2013 Curriculum holds the existing learning in constructivism theory [41]. More specifically, activities such as observing, questioning, reasoning and experimenting the scientific approach display the characteristics of constructivism learning. Therefore, it can be said that the scientific approach is similar to the constructivist approach.

The next discussed similarity is the formative learning approach and the formative feedback mechanism. Generally, the formative learning approach as well as the formative feedback mechanism can be integrated in all parts of the lesson. Basically, both curricula have three parts of learning activity: pre-activity, whilst activity, and post-activity. The feedback is always needed in the learning process as it can help to check how far the students understand the topic. In this pedagogic standard, all activities are considered forming students' knowledge development. Both curricula then follow the cognitive development process which compromises remembering, understanding, applying, analyzing, evaluating, and creating.

Afterwards, the tasks that the students sometimes need to complete in Indonesia and the Philippines are written and performance such as quizzes and role-play. The tasks of the Philippines' English curriculum are even drawn clearly in its DepEd Order [36]. Checking the students' comprehension can be done not only through giving written questions but also oral activity such as asking and answering session. However, both curricula have the three types of assessment: assessment of learning (formative assessment), assessment for learning (summative assessment), and assessment as learning (continuous assessment) [42]. Additionally, formative assessment should not be confused since it has different ways and purposes with summative assessment.

The next similarity is set on learning sources and technologies. In spite of learning English differently, the two curricula are also similar in using books, internet sources, and electronic generated slides as the resource and technology. Certain technologies are used to support different English teaching [43]. Teaching English by using a grammar-translation method can rely on a blackboard, while an audiolingual method can use audiotape and a communicative language 
teaching needs to use technologies, which support to authentic materials. It means whether it is EFL or ESL, the same technology can be used in each class.

The next is a classroom seating arrangement. With the seating arrangement in an orderly row and letter $\mathrm{U}$ or following the necessity, both Indonesia and Philippines consider the appropriate condition for supporting the learning process. In step with seating arrangements have the potential to assist preventing problem behaviors that decline students' attention and reduce available instructional time [44]. Additionally, the teacher should allocate the seating arrangements that are appropriate to the type of learning activities such as let the learners sit in a circle as they work in pairs or groups.

Moving to differences, the two curricula lie on the timings. For gaining the knowledge of English, the Philippines set 240 minutes per week and 160 minutes in Indonesia. Because English as an ESL in the Philippines, they have more time to learn it, and EFL setting (as in Indonesia) often involves limited contact hours [45].

The last difference is the environment. Both EFL and ESL students can learn in another environment or outside the classroom through group work or homework. However, in an ESL situation, the students not only acquire English in their surroundings, but also use English either in or outside the classroom since their environment supports for it. While in an EFL situation, the students learn English only in the classroom or school environment and continue to speak in their own language once they go outside the classroom. It is beneficial to consider the pedagogical consequences for a context range from high visibility, equipped with the target of language outside the class to no access beyond the class. There are many reasons for learning English and lots of totally different circumstances in which English can be adapted, so it is not surprising that there is an enormous selection of teaching approaches. It cannot be assumed that one approach will be suitable for all students in all conditions.

Evaluation Standard/Summative Assessment. Originally, both Indonesia and the Philippines' English curriculum assess three generic domains of competence: behavior, knowledge, and skill [46] and [36]. Yet, they are different in managing those aspects. As the final result, Indonesia has three different scores for three aspects written in the students' rapport, while the Philippines combine them as one score.

The mastery learning represents in students' rapport using a predicate and score in Indonesia, while it is only the predicate in the Philippines. The follow-up for students' achievement is remediation. It means the students who do not pass the mastery learning should take the remediation. 
The Special Characteristics of Indonesia and the Philippines' English Curriculum. There are some special characteristics of Indonesia and the Philippines' English practice that might be adopted. The first is both curricula have taken advantage of today's sophisticated technology. In Indonesia, the teacher put the learning sources from the internet into the learning process, and they even connects to the internet, while the learning process is happening. While in the Philippines, the teacher applies flipped classroom. Flipped classroom is a leaner-centeredness approach dealing with two segments of interactive activities, taking course materials from the computer at home while engaging the concepts in the classroom under the guidance of a teacher [47]. With this approach, a teacher can increase the interactive period within the class because the students have got the materials at home and can discuss it directly with the teacher. Obviously, the advancement of technology affects the English language teaching in these two countries. The way the Philippines implements it might be adopted by Indonesia or vice versa.

Secondly, both curricula put building responsibility among the students as a concern. In Indonesia, the character of responsibility is set on the teacher's journal and marked anytime the teacher finds it through observation. In the Philippines, the teacher also intends to build responsibility among the students through real action, that is, seating arrangement. They are responsible to their seatmate. So, if one of them is too noisy and then the seatmate will be represented to give them discipline. Implementing real action to build the students' character might be adopted by each country.

The third is they assess the students' attitude authentically through a proof. In Indonesia, the teacher has journal or observation sheet to observe their attitude authentically. In the Philippines, the teacher has index card. The index card contains with students' picture and identity. It is used to mark the students, their attitude and absent. It is approximately 8x6 square meters and it is easy to be hold during the lesson. The teachers just bring their prior knowledge of the students' attitude value and write down important information. The picture can also help them remembers the students. Briefly, Indonesia has a set of complete instrument in assessing the students' attitude and the Philippines have a simple instrument for that. In addition, the Philippines implement what Indonesia does in a special subject, namely, Good Manners and Right Conduct (GMRC) subject. In 2019, the eighteenth congress introduced that the GMRC subject can provide the holistic concept of character development and moral values formation [48].

The last is veering away from valuing only academic achievement based on high grades. In Indonesia, putting ranking based on students' grades has been removed in the students' report. It depends on the teachers or school if they want to give it or not. While in the Philippines, giving awards and recognition is regulated in DepEd Order No. 36 of 2016 [36], in order to support of the holistic development of Filipino learners. It is important to move toward valuing and celebrating a wide range of student achievements covering excellence in academic, leadership, and social responsibility. It recognizes that each student owns unique strengths that need to be identified, strengthened, and publicly acknowledged.

Generally, if it is seen through the component of the curriculum between Indonesia and the Philippines they are almost similar, they are just different in the selection of the learning areas. Therefore, there are two sides that argue about the EFL-ESL distinction because they are almost similar in learning English. However, ELT should be organized following a certain principle. A curriculum must be formulated following philosophical principles, psychological principles, sociological principles, and miscellaneous principles. Additionally, Indonesia and the Philippines' 
English curriculum have followed a number of sequential stages in developing a curriculum. They are aim and objectives, curriculum standard (learning objects), pedagogic standard, and evaluation standard.

\section{Conclusion}

Indonesia's EFL Curriculum and the Philippines' ESL Curriculum have similarities and differences. The similarities are the aim and objectives both curricula have the intention to enhance English communicative and literacy skills. Interpersonal and transactional texts, functional texts, and monolog texts are the learning objects of Indonesia's EFL curriculum for grade 9. While the learning objects of the Philippines' ESL curriculum are some selections of Anglo-American Literature. The similar pedagogic standard between Indonesia and the Philippines' English curriculum is seen from the pedagogic mode, types of learning approach, formative learning approach (including formative assessment), feedback mechanisms, tasks, sources and technologies, and the seating arrangement. The last, both curricula apply authentic assessment holistically. They assess knowledge, skill, and character through an exact guidance. Yet, they are different in organizing the assessment. Moreover, they are different on time allocation, and their environment.

A few special characteristics of Indonesia and the Philippines' curriculum practices are: (1) both curricula have taken advantage of advanced technologies, (2) both curricula positioned building responsibility among the students as a concern, (3) they assess students' attitude authentically through an evidence, and (4) they veer away from valuing only academic achievement based on excessive grades.

\section{References}

[1] L. Alsagoff, S. L. McKay, G. Hu, and W. A. Renandya, Eds., Principles and Practices for Teaching English as an International Language. New York: Routledge Taylor \& Francis Group, 2012.

[2] Y. Iwai, "The Effects of Metacognitive Reading Strategies: Pedagogical Implications for EFL/ESL Teachers," Reading, vol. 11, no. 2, pp. 150-159, 2011, [Online]. Available: http://readingmatrix.com/articles/april_2011/iwai.pdf.

[3] C. Brandt, Success on Your Certificate Course in English Language Teaching: A Guide to Becoming a Teacher in ELT/TESOL, London. SAGE Publications Ltd, 2006.

[4] S. Kumari and D. S. Srivastava, Curriculum and Instruction. Delhi: Isha Books, 2005.

[5] D. Scott, Curriculum and Assessment. London: Ablex Publishing, 2001.

[6] A. Ross, Curriculum: Construction and Critique. London: Falmer Press, 2000.

[7] J. C. Richards, "Curriculum approaches in language teaching: Forward, central, and backward design," RELC J., vol. 44, no. 1, pp. 5-33, 2013, doi: 10.1177/0033688212473293.

[8] B. Sahu, The New Educational Philosophy. New Delhi: Sarup and sons, 2002.

[9] D. Scott, New Perspectives on Curriculum, Learning and Assessment. London: Springer, 2016.

[10] N. Noddings, "Aims, Goals, and Objectives," vol. 8, pp. 7-15, 2007. 
[11] F. C. Lunenburg, "Key Components of a Curriculum Plan: Objectives, Content, and Learning Experiences," Schooling, vol. 2, no. 1, pp. 2-5, 2011, [Online]. Available: http://www.nationalforum.com/Electronic Journal Volumes/Lunenburg, Fred C. Components of a Curriculum Plan Schooling V2 N1 2011.pdf.

[12] L. B. Nilson, Teaching at Its Best: A Research-Based Resource for College Instructors, 3rd Editio. New York: Jossey-Bass, 2010.

[13] N. M. Yuniari, P. K. Nitiasih, and I. G. Budasi, "Developing Supplementary English Teaching Materials for the Tenth Year Students of SMA PGRI 6 Denpasar in Implementing Curriculum 2013," e-Journal Progr. Pascasarj. Univ. Pendidik. Ganesha, vol. 3, 2014, [Online]. Available: https://undiksha.ac.id/informasi-publikasi-jurnal-pascasarjanaundiksha/ejournal-pascasarjana-undiksha/.

[14] I. Sukowati, N. Suryani, and M. Yusuf, "the Implementation of Curriculum 2013 in Handicap Children At Slb D Ypac Surakarta, Indonesia,” Eur. J. Spec. Educ. Res., vol. 2, no. 4, pp. 76-93, 2017, doi: 10.5281/zenodo.839353.

[15] J. Cordova, "Curriculum Comparison of Philippines' K-12 and Thailand 's Basic Education Core Curriculum of 2008," no. December, 2019, doi: 10.13140/RG.2.2.33495.01443.

[16] A. Abduh and R. Rosmaladewi, "Language policy, identity, and bilingual education in Indonesia: A historical overview," XLinguae, vol. 12, no. 1, pp. 219-227, 2019, doi: 10.18355/XL.2019.12.01.17.

[17] D. A. Gunantar, "the Impact of English As an International Language on English Language Teaching in Indonesia," Impact English As an Int. Lang. English Lang. Teach. Indones., vol. 10, no. 2, pp. 141-151, 2016, doi: 10.15294/lc.v10i2.5621.

[18] B.-M. Chang, "The roles of English language education in Asian context," J. Pan-Pacific Assoc. Appl. Linguist., vol. 15, no. 1, pp. 191-206, 2011.

[19] S. Wa-Mbaleka, "Teaching English to Speakers of Other Languages: The Case of the Philippines," Int. J. Acad. Res. Progress. Educ. Dev., vol. 3, no. 3, pp. 64-78, 2014, doi: 10.6007/ijarped/v3-i3/952.

[20] S. B. Merriam and E. J. Tisdell, Qualitative Research: A Guide to Design and Implementation, 4th Editio. San Fransisco: Jossey-Bass Inc., 2015.

[21] M. Alston and W. Bowles, Research for Social Workers: An Introduction to Methods, 3rd Editio. 2019.

[22] D. G. Hays and A. A. Singh, Qualitative Inquiry in Clinical and Educational Settings. New York: The Guilford Press, 2012.

[23] N. M. Bradburn, S. Sudman, and B. Wansink, Asking Questions: The Definitive Guide to Questionnaire Design - For Market Research, Political Polls, and Social and Health Questionnaires, Revised Ed. San Fransisco: Jossey-Bass, 2004.

[24] K. Roulston, Reflective Interviewing: A Guide to Theory and Practice. London: Sage Publications, Ltd., 2010.

[25] D. T. Griffee, An Introduction to Second Language Research Methods: Design and Data. eBook edition. Berkeley, California: TESL-EJ Publications, 2012.

[26] U. Flick, Designing Qualitative Research. London: SAGE Publications Ltd, 2007.

[27] J. R. Fraenkel, N. E. Wallen, and H. H. Hyun, How to Design and Evaluate Research in Education, 8th Editio. New York: McGraw-Hill Higher Education, 2012.

[28] G. A. Bowen, Document analysis as a qualitative research method, vol. 9, no. 2. 2009. 
[29] J. Jonker and B. W. Pennink, The Essence of Research Methodology: A Concise Guide for Master and PhD Students in Management Science. Germany: Springer, 2010.

[30] L. Cohen, L. Manion, and K. Morrison, Research Methods in Education. New: Routledge Taylor \& Francis Group, 2007.

[31] P. Bazeley, Qualitative Data Analysis: Practical Strategies. London: SAGE Publications Ltd, 2013.

[32] M. Q. Patton, Qualitative Research \& Evaluation Methods. Integrating Theory and Practice. New York: SAGE Publications, Inc, 2014.

[33] Kemendikbud, "Permendikbud No. 37 tahun 2018 tentang Kompetensi Inti dan Kompetensi Dasar Pelajaran pada Kurikulum 2013 pada Pendidikan Dasar dan Pendidikan Menengah,” 2016.

[34] Kemendikbud, Buku Guru: Bahasa Inggris: Think Globally Act Locally. Jakarta: Kemendikbud, 2015.

[35] L. W. Anderson et al., A Taxonomy for Learning, Teaching and Assessing: A Revision of Bloom's Taxonomy of Educational Objectives, A Bridge E. New York: Addison Wesley Longman, Inc., 2001.

[36] DepEd, "K to 12 Curriculum Guide," no. July, p. 247, 2016, [Online]. Available: http://www.deped.gov.ph/sites/default/files/page/2017/English CG!.pdf.

[37] American Library Association, Information Literacy Competency Standards for Higher Education. Chicago, Illinois: A division of the American Library Association, 2000.

[38] S. N. W. Sari and N. A. K. Wardani, "An Analysis of Indonesia's 2013 EFL Curriculum and Turkey's National English Language Curriculum for Secondary Schools," IJELTAL (Indonesian J. English Lang. Teach. Appl. Linguist., vol. 3, no. 1, p. 23, 2018, doi: 10.21093/ijeltal.v3i1.113.

[39] T. T. M. Van, "The Relevance of Literary Analysis to Teaching Literature in the EFL Classroom, English Teaching Forum, 2009," English Teach. Forum, vol. 47, no. 3, pp. 2-9, 2009, [Online]. Available: https://eric.ed.gov/?id=EJ923454.

[40] R. I. Shazu, "Use of Literature Teaching and Learning: A Critical Assessment," J. Educ. Pract., vol. 5, no. 7, pp. 29-35, 2014, [Online]. Available: www.iiste.org.

[41] H. P. Waseso, "Kurikulum 2013 Dalam Prespektif Teori Pembelajaran Konstruktivisme," Ta'lim, vol. 1, no. 1, pp. 59-72, 2018.

[42] N. A. Hebron, "Exploring Teachers 'Experiences of Teaching CAPS Life Skills ( Physical Education ) in the Foundation Phase," University of KwaZulu-Natal, 2015.

[43] A. M. Abunowara, "Using technology in EFL/ESL classroom," Int. J. Humanit. Cult. Stud., vol. 1(2), pp. 1-8, 2014.

[44] R. Wannarka and K. Ruhl, "Seating arrangements that promote positive academic and behavioural outcomes: A review of empirical research," Support Learn., vol. 23, no. 2, pp. 89-93, 2008, doi: 10.1111/j.1467-9604.2008.00375.x.

[45] K. R. Rose, Teachers and students learning about request in Hong Kong. In Culture in second language teaching and learning. Cambridge: Cambridge University Press, 1999.

[46] Kemendikbud, "Permendikbud No. 21 Tahun 2016 - Standar Isi Pendidikan Dasar dan Menengah," 2016.

[47] J. L. Bishop and M. A. Verleger, "The flipped classroom: A survey of the research," ASEE Annu. Conf. Expo. Conf. Proc., no. August, 2013. 
[48] Republic of the Philippines, "An Act Institutionalizing Good Manners and Right Conduct (GMRC) in the K to 12 Curriculum," Congr. Philipp., vol. 11476, 2019. 